University of Nebraska - Lincoln

DigitalCommons@University of Nebraska - Lincoln

\title{
Performance of Mouse Lines Divergently Selected for Heat Loss When Exposed to Different Environmental Temperatures. II. Feed Intake, Growth, Fatness, and Body Organs
}

\author{
P. M. Kgwatalala \\ Botswana College of Agric. \\ Merlyn K. Nielsen \\ University of Nebraska-Lincoln, mnielsen1@unl.edu
}

Follow this and additional works at: https://digitalcommons.unl.edu/animalscifacpub

Part of the Animal Sciences Commons

Kgwatalala, P. M. and Nielsen, Merlyn K., "Performance of Mouse Lines Divergently Selected for Heat Loss When Exposed to Different Environmental Temperatures. II. Feed Intake, Growth, Fatness, and Body Organs" (2004). Faculty Papers and Publications in Animal Science. 516.

https://digitalcommons.unl.edu/animalscifacpub/516

This Article is brought to you for free and open access by the Animal Science Department at DigitalCommons@University of Nebraska - Lincoln. It has been accepted for inclusion in Faculty Papers and Publications in Animal Science by an authorized administrator of DigitalCommons@University of Nebraska - Lincoln. 


\title{
Performance of mouse lines divergently selected for heat loss when exposed to different environmental temperatures. II. Feed intake, growth, fatness, and body organs ${ }^{1}$
}

\author{
P. M. Kgwatalala ${ }^{2}$ and M. K. Nielsen ${ }^{3}$ \\ Department of Animal Science, University of Nebraska, Lincoln 68583-0908
}

\begin{abstract}
Mouse populations differing in metabolic rate have been developed through selection for high (MH) and low (ML) heat loss, along with the unselected controls (MC). Objectives of the study were to compare the MH, ML, and MC lines for feed intake, growth, body fatness, and organ weights when reared at 12,22 , and $31^{\circ} \mathrm{C}$, and investigate potential line $\times$ environment interactions. Feed intake was recorded weekly from 3 to 9 wk of age, and BW at 3, 6, and 9 wk of age. Body fat percent and organ weights were measured at $9 \mathrm{wk}$ of age. No line $\times$ environment interactions were detected for any of the traits measured. The MH mice consumed more feed than ML mice from 5 to 9 wk of age. Between 8 and 9 wk of age, MH mice consumed $13 \%$ more feed than the ML mice, but they were relatively leaner ( 14.45 vs. $16.32 \%$ body fat); MC mice were intermediate for both traits. Mice in the cold
\end{abstract}

environment consumed the greatest amount of feed, and those in the hot environment consumed the least. Males consumed more feed than females, and the difference was greater in the cold than in the hot environment. No differences in BW were found between the lines. Mice in the $22^{\circ} \mathrm{C}$ environment were heavier than their age-matched counterparts in the other two environments, and males were heavier than females at all ages. Relative to BW, the three lines had similar tail length, body length, and liver weight. Mice in the cold environment had heavier spleens and livers than those in the hot environment but relatively shorter bodies and tails; the normal environment was intermediate for these traits. Results from this study indicate that selection to decrease maintenance requirements did not produce mice with any less ability to grow and perform under an array of environmental temperatures.

Key Words: Ambient Temperature, Body Composition, Feed Intake, Growth, Interactions, Mice

(C2004 American Society of Animal Science. All rights reserved.

J. Anim. Sci. 2004. 82:2884-2891

\section{Introduction}

An important variable affecting profitability of livestock enterprises is feed intake. Considerable variation in maintenance feed energy requirement exists among animals of a certain breed and size, and part of this variation is the result of genetic causes. Selection for lower maintenance requirement can lower costs of livestock production. Feed intake is also subject to environmental influences. Temperature is one factor influencing feed intake and other correlated traits, such as growth. For animals reared under extensive conditions,

\footnotetext{
${ }^{1}$ A contribution of the Univ. of Nebraska Agric. Res. Div., Lincoln, Journal Series No. 14213. This research was supported in part by funds provided through the Hatch Act.

${ }^{2}$ Current address: Botswana College of Agric., Private Bag 0027, Gaborone, Botswana.

${ }^{3}$ Correspondence: A218 Animal Science (phone: 402-472-6406; fax: 402-472-6362; e-mail: mnielsen1@unl.edu).

Received December 5, 2003.

Accepted June 14, 2004.
}

seasonal variations in temperature may create stressful conditions such that reduction of maintenance energy requirements is harmful.

Mouse populations differing in maintenance energy requirements have been developed through selection for high (MH) and low (ML) heat loss, along with unselected controls (MC), as described by Nielsen et al. (1997b). Nielsen et al. (1997a) and Moody et al. (1997) reported that the ML mice are fatter than the MH mice, with the MC mice being intermediate. Subjecting the $\mathrm{MH}, \mathrm{MC}$, and ML mice to various environmental temperatures might reveal possible consequences of selecting for lower maintenance energy requirements in livestock.

The $a$ priori hypothesis for the study was that ML mice have a lower thermal conductance and greater fat insulation than $\mathrm{MH}$ mice and should therefore perform better than $\mathrm{MH}$ mice in the cold environment. The $\mathrm{MH}$ mice have a greater thermal conductance and less fat insulation than ML mice and should have a comparative advantage in the hot environment, resulting in significant line $\times$ environment interactions. The pur- 
pose of this study was therefore to evaluate whether there are interactions between lines selected for heat loss or metabolic rate and environmental temperatures $\left(12,22\right.$, and $\left.31^{\circ} \mathrm{C}\right)$ for growth, feed intake, body fat, and weights of some body organs.

\section{Materials and Methods}

\section{Experimental Animals}

Kgwatalala et al. (2004) describes the parents of these animals, also measured in the three different thermal temperatures, as well as the experimental animals themselves. Animals came from three independent, unique replicates of three selection lines $(\mathrm{MH}$, ML, MC). Mice sampled for this study came from Generation 38, Replicate 3, and Generation 39, Replicates 1 and 2 .

\section{Facilities}

Three environmentally controlled rooms were used in the investigation. The three rooms that served as the cold $(\mathbf{C})$, normal $(\mathbf{N})$, and hot $(\mathbf{H})$ environmental treatments were kept at 12,22 , and $31^{\circ} \mathrm{C}$, respectively. Kgwatalala et al. (2004) provides further description of the facilities.

\section{Management}

Kgwatalala et al. (2004) provides a detailed description of the management of the parents and the subsequent pups measured in the present research. Parents were mated and the dams produced the litters in the three temperature environments. Upon giving birth, the number of pups born per dam was standardized to eight (ideally four males and four females) within $1 \mathrm{~d}$. Pups were individually identified and weaned at $3 \mathrm{wk}$ of age.

Pups were housed in groups of six per cage for females and groups of four per cage for males, for an intended total of 42 females and 40 males of each selection line and replicate across all environmental treatments. Due to breeding failure and poor survival of some pups in the $\mathrm{C}$ environment, a few of the line-replicate-environment classes had fewer animals. But all classes had at least 30 animals, except $\mathrm{MH}$ females of Replicate 3 in the $\mathrm{C}$ environment, which totaled 18. Pups had ad libitum access to water and a regular maintenance diet $(24 \%$ $\mathrm{CP}, 4 \%$ crude fat, and $4.5 \%$ crude fiber, as-fed basis; Teklad 8604, Harlan Teklad, Madison, WI) up to $9 \mathrm{wk}$ of age, at which time, the experiment was terminated. All research activity was conducted under the IACUC Protocol No. 01-09-062.

\section{Measurement of Traits}

Body weight was recorded on an individual basis at 3,6 , and 9 wk of age. Feed intake was recorded in the generation of pups born under the three environments.
Feed intake (as-fed basis) was recorded per cage on a weekly basis (weight of feed at start of week minus weight at end of week) from weaning (3 wk of age) up to $9 \mathrm{wk}$ of age. Weekly feed intake data were divided by the number of animals per cage to estimate feed intake per animal each week. The average weights of the animals during the collection of feed intake data also were determined on per-cage basis and later transformed to metabolic weights $\left(\mathrm{kg}^{0.75}\right)$. For each cage, weekly average animal feed intake per unit metabolic weight per day was determined.

Body dimensions and weights of body organs were recorded at the end of the study (9 wk of age). Ten mice of each sex in each line-replicate-environment class were killed randomly for measurements of body organs. An individual's weight was first determined, and then the animal was killed using carbon dioxide asphyxiation. Percentage of body fat was determined using a PIXImus dual x-ray densitometer (model 30200, Lunar Corp., Madison, WI). Body length (from nose tip to anus) and tail length were measured using a standard 300$\mathrm{mm}$ ruler. Fresh weights of the liver, tail, and spleen were determined. Organ weights were analyzed as a percentage of the animal's live BW of. Body length and tail length for each animal were divided by the animal's BW (i.e., expressed relative to BW) to make meaningful comparisons among different treatment groups.

\section{Statistical Analyses}

Three levels of temperature environments $(12,22$, and $31^{\circ} \mathrm{C}$ ), three lines of mice ( $\mathrm{MH}, \mathrm{ML}$, and $\mathrm{MC}$ ), three replicates, and the two sexes (males and females) were used in a $3 \times 3 \times 3 \times 2$ factorial arrangement in a completely randomized design. Data analyses were by SAS (SAS Inst., Inc., Cary, NC) using mixed-model procedures of Littell et al. (1996). The Satterthwaite method for determining degrees of freedom was used in all analyses. The experimental model for BW, feed intake, organ weight, and body fat data included environment, line, sex, and the various interactions between the three factors as fixed effects. Random effects were replicates and the interactions between replicates and environment, line, environment $\times$ line, and environment $\times$ line $\times$ sex.

Mean separations for the various fixed factors and the interactions between the fixed factors were done using sets of orthogonal contrasts. Selection criteria means were compared using orthogonal contrasts of 1) $[(\mathrm{MH}+\mathrm{ML}) / 2-\mathrm{MC}]$ to test for asymmetry of selection; and 2) MH vs. ML to test for selection response. Thermal environment effects were compared using orthogonal contrasts of 3) $[(\mathrm{H}+\mathrm{C}) / 2-\mathrm{N})]$ to test for nonlinear effects of temperature; and 4) $\mathrm{H}$ vs. $\mathrm{C}$ to test for the extreme effects of temperature. The remaining contrasts were tests for males vs. females and the various two- way and three-way interactions of line, environment, and sex. 
Table 1. Least squares means $\left( \pm S E\right.$ ) for feed intake (as-fed basis; $\mathrm{g} \cdot \mathrm{kg}^{-0.75} \cdot \mathrm{d}^{-1}$ ), collected in group cages but expressed on an individual animal basis, by line at different ages of the mice ${ }^{\mathrm{a}}$

\begin{tabular}{lcccccc}
\hline \hline Line & 3 to $4 \mathrm{wk}$ & 4 to $5 \mathrm{wk}$ & 5 to $6 \mathrm{wk}^{\mathrm{b}}$ & 6 to $7 \mathrm{wk}^{\mathrm{c}}$ & 7 to $8 \mathrm{wk}^{\mathrm{d}}$ & 8 to $9 \mathrm{wk}^{\mathrm{e}}$ \\
\hline MH & $79.85 \pm 2.83$ & $89.40 \pm 2.23$ & $87.13 \pm 1.28$ & $84.94 \pm 1.32$ & $84.33 \pm 2.03$ & $82.44 \pm 2.72$ \\
MC & $75.74 \pm 2.82$ & $85.56 \pm 2.22$ & $84.43 \pm 1.27$ & $80.36 \pm 1.31$ & $79.96 \pm 2.02$ & $76.52 \pm 2.71$ \\
ML & $77.46 \pm 2.82$ & $87.83 \pm 2.22$ & $82.18 \pm 1.27$ & $75.13 \pm 1.31$ & $73.46 \pm 2.02$ & $72.66 \pm 2.71$ \\
\hline
\end{tabular}

${ }^{\mathrm{a}} \mathrm{MH}=$ selected for high heat loss; $\mathrm{MC}=$ control; $\mathrm{ML}=$ selected for low heat loss.

bignificant contrast: $\mathrm{MH}-\mathrm{ML}, P<0.04$.

'Significant contrast: $\mathrm{MH}-\mathrm{ML}, P<0.002$.

${ }^{\mathrm{d}}$ Significant contrast: $\mathrm{MH}-\mathrm{ML}, P<0.02$.

eSignificant contrast: MH - ML, $P<0.01$.

Data are summarized by significance of contrasts. Least squares means $( \pm \mathrm{SE})$ are presented. Main effects are reported only for those factors not involved in any significant interactions; otherwise, simple effects of the factors involved in a significant interaction are reported at different levels of both factors. No three-way interactions were significant and thus are not discussed.

\section{Results and Discussion}

\section{Feed Intake}

Least squares means for feed intake $\left(\mathrm{g} \cdot \mathrm{kg}^{-0.75} \cdot \mathrm{d}^{-1}\right)$, collected in group cages and expressed on an individualanimal basis, for all the lines from $3 \mathrm{wk}$ to $9 \mathrm{wk}$ of age are in Table 1 . No line $\times$ environment interactions were detected for feed intake at any age. At 3 to 4 wk and 4 to $5 \mathrm{wk}$ of age, there were no differences $(P>0.10)$ in feed intake between the lines. Maximum feed intake occurred between 4 and 5 wk of age and averaged 85.56, 89.40 , and $87.83 \mathrm{~g} \cdot \mathrm{kg}^{-0.75} \cdot \mathrm{d}^{-1}$ for the MC, MH, and ML lines, respectively. From 5 to 6 wk of age until the end of the study, there was a divergence $(P<0.05)$ in feed intake between the $\mathrm{MH}$ and ML lines. Feed intake in the MC line was intermediate to intakes in the ML and MH lines during the same period. Feed intake, adjusted for animal size, increased very rapidly from the 3- to 4-wk period to the 4- to 5-wk period and then declined for all lines until the end of the study. At 3 to $4 \mathrm{wk}$ of age or during wk 1 postweaning, the $\mathrm{MH}$ line consumed about $3 \%$ more feed than the ML line and $13 \%$ more at 8 to $9 \mathrm{wk}$ of age.

Nielsen et al. (1997a) reported greater feed intake in the $\mathrm{MH}$ than in the ML line and also noted that the difference in feed intake between the two lines at 9 to $11 \mathrm{wk}$ of age relative to the MC means, ranged from $10.5 \%$ at Generation 10 to $20.6 \%$ at Generation 15 of selection for heat loss. Data in that study were collected at an environmental temperature of $22^{\circ} \mathrm{C}$. In the current study, the difference in feed intake between the MH and ML lines started to occur at 5 to $6 \mathrm{wk}$ of age and then increased with age. Studies in mice lines divergently selected for voluntary feed intake by Selman et al. (2001) revealed significantly higher resting metabolic rates and thermal conductance in the high intake line than in the low intake line to be the main causes of the disparity in feed intake between the lines.

Least squares means for feed intake per day, adjusted for average metabolic size in the cage for males and females under different environmental conditions at different ages, are shown in Table 2. There were environment $\times$ sex interactions $(P<0.05)$ at all ages. Differences in feed intake between males and females were greater in the $\mathrm{C}$ environment than in the $\mathrm{H}$ environment. From 6 wk of age, the differences in feed intake between the average of the $\mathrm{H}$ plus $\mathrm{C}$ environments and the $\mathrm{N}$ environment were greater in males than females $(P<0.03)$ also contributing to the significant environment $\times$ sex interaction. Under all environmental conditions, males consistently consumed more feed than females at all ages.

Also, feed intake was different $(P<0.001)$ at all ages between animals raised in the $\mathrm{C}$ and $\mathrm{H}$ environments (Table 2). Animals in the $\mathrm{C}$ environment consistently consumed more feed than their age-matched counterparts in the $\mathrm{H}$ environment. Feed intake in the $\mathrm{N}$ environment was intermediate to intakes in the $\mathrm{C}$ and $\mathrm{H}$ environments; however, from 5 to 9 wk of age, feed intake in the $\mathrm{N}$ environment was less $(P<0.002)$ than the average of the $\mathrm{H}$ plus $\mathrm{C}$ environment intakes.

The increased feed intake in the $\mathrm{C}$ environment is consistent with the findings of Young (1994), who reported that outdoor and communal populations of mice responded to a reduction in temperature from a 22 to $24^{\circ} \mathrm{C}$ range to a colder 3 to $7^{\circ} \mathrm{C}$ range by increasing their feed intake from 0.18 to 0.32 and 0.20 to $0.37 \mathrm{~g}$ of feed/g of BW, respectively. Jesse et al. (1991) also observed that finishing swine subjected to a cold diurnal temperature between -5 to $8^{\circ} \mathrm{C}$ consumed more feed (3.88 vs. $3.67 \mathrm{~kg} / \mathrm{d})$ than their thermoneutral counterparts maintained at $20^{\circ} \mathrm{C}$. The decreased feed intake by mice in the $\mathrm{H}$ environment is also consistent with the findings of Lopez et al. (1991), who reported a reduction in feed intake ( $3.01 \mathrm{vs} .3 .38 \mathrm{~kg} / \mathrm{d}$ ) in finishing swine subjected to a daily diurnal temperature between 22.5 and $35^{\circ} \mathrm{C}$ compared with pigs maintained at $20^{\circ} \mathrm{C}$ (thermoneutral). Increased feed intake in the $\mathrm{C}$ environment is consistent with the expected increase in the rate of metabolism required for the maintenance of a constant body temperature. In the $\mathrm{H}$ environment, the rate of 
Table 2. Least squares means $\left( \pm S E\right.$ ) for feed intake (as-fed basis; $\mathrm{g} \cdot \mathrm{kg}^{-0.75} \cdot \mathrm{d}^{-1}$ ), collected in group cages but expressed on an individual animal basis, by environmental temperature-sex classes at different ages of the mice

\begin{tabular}{|c|c|c|c|c|c|c|}
\hline \multirow[b]{2}{*}{ Age, wk ${ }^{\mathrm{ab}}$} & \multicolumn{2}{|c|}{ Cold $\left(\mathrm{C}, 12^{\circ} \mathrm{C}\right)$} & \multicolumn{2}{|c|}{ Normal $\left(\mathrm{N}, 22^{\circ} \mathrm{C}\right)$} & \multicolumn{2}{|c|}{ Hot $\left(\mathrm{H}, 31^{\circ} \mathrm{C}\right)$} \\
\hline & Males & Females & Males & Females & Males & Females \\
\hline 3 to 4 & $98.27 \pm 3.12$ & $89.38 \pm 3.19$ & $76.46 \pm 3.06$ & $70.56 \pm 3.12$ & $68.22 \pm 3.06$ & $63.19 \pm 3.12$ \\
\hline 4 to $5^{\mathrm{c}}$ & $114.30 \pm 3.26$ & $103.45 \pm 3.30$ & $85.05 \pm 3.21$ & $81.85 \pm 3.25$ & $72.39 \pm 3.21$ & $68.54 \pm 3.25$ \\
\hline 5 to $6^{\mathrm{d}}$ & $116.39 \pm 1.16$ & $108.16 \pm 1.26$ & $80.49 \pm 1.29$ & $76.54 \pm 1.40$ & $64.97 \pm 1.07$ & $60.91 \pm 1.16$ \\
\hline 6 to $7^{\mathrm{e}}$ & $117.64 \pm 1.45$ & $106.16 \pm 1.56$ & $72.46 \pm 1.36$ & $67.58 \pm 1.45$ & $61.14 \pm 1.36$ & $55.90 \pm 1.45$ \\
\hline 7 to $8^{\mathrm{e}}$ & $114.86 \pm 1.91$ & $104.88 \pm 1.98$ & $71.85 \pm 1.84$ & $68.47 \pm 1.90$ & $59.91 \pm 1.84$ & $55.51 \pm 1.90$ \\
\hline 8 to $9^{\text {e }}$ & $113.51 \pm 2.80$ & $102.78 \pm 2.85$ & $69.64 \pm 2.75$ & $66.37 \pm 2.79$ & $57.28 \pm 2.75$ & $53.67 \pm 2.79$ \\
\hline
\end{tabular}

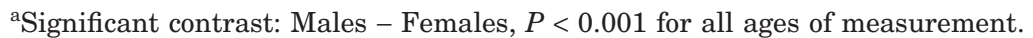

bSignificant contrast: $\mathrm{H}-\mathrm{C}, P<0.001$ for all ages of measurements.

'Significant contrast: $[\mathrm{H}-\mathrm{C}] \times[$ Males - Females $], P<0.001$.

${ }^{\mathrm{d}}$ Significant contrasts: $(\mathrm{H}+\mathrm{C}) / 2-\mathrm{N}, P<0.001 ;[\mathrm{H}-\mathrm{C}] \times$ [Males - Females], $P<0.03$.

eSignificant contrasts: $(\mathrm{H}+\mathrm{C}) / 2-\mathrm{N}, P<0.002 ;[(\mathrm{H}+\mathrm{C}) / 2-\mathrm{N}] \times[$ Males - Females], $P<0.03 ;[\mathrm{H}-\mathrm{C}] \times$ [Males - Females], $P<0.002$.

metabolism is decreased to minimize heat production hence the observed decrease in feed intake.

A nonsignificant line $\times$ environment interaction for feed intake at different ages of the mice implies that the differences in feed intake between the lines in the $\mathrm{N}$ environment persisted under extreme environmental temperatures. The lines were thus similarly affected by different environmental temperatures. Direct selection for lower maintenance requirements in livestock might therefore result in animals that consistently consume less feed than their unselected counterparts under greatly differing environmental temperatures, although species differences may exist.

\section{Body Weight}

Least squares means for BW of animals of the three lines at different ages are in Table 3 . There were no line $\times$ environment interactions for $\mathrm{BW}$ of the mice at any age. There were also no differences between the lines in BW at all ages $(P>0.10)$, although the $\mathrm{MC}$ line had the greatest BW at all ages.

In all the lines, more rapid growth occurred between 3 and 6 wk of age than between 6 and 9 wk of age. This is consistent with the greater feed intake per unit metabolic size that occurred in the first 2 wk postweaning. The average growth rate for all the lines between 3 and $6 \mathrm{wk}$ of age was $0.61 \mathrm{~g} / \mathrm{d}$, compared with $0.19 \mathrm{~g} /$ d between 6 and 9 wk of age. Nielsen et al. (1997a) reported no significant divergence between the $\mathrm{MH}$ and

Table 3. Least squares means ( \pm SE) for body weight (g) by selection line at different ages of the mice ${ }^{\mathrm{a}}$

\begin{tabular}{lccc}
\hline \hline Age, wk & MH & MC & ML \\
\hline 3 & $12.93 \pm 0.49$ & $13.70 \pm 0.49$ & $12.86 \pm 0.49$ \\
6 & $24.86 \pm 0.71$ & $26.63 \pm 0.71$ & $26.49 \pm 0.71$ \\
9 & $28.63 \pm 0.75$ & $30.87 \pm 0.75$ & $30.14 \pm 0.75$ \\
\hline
\end{tabular}

${ }^{\mathrm{a}} \mathrm{MH}=$ selected for high heat loss; $\mathrm{MC}=$ control; $\mathrm{ML}=$ selected for low heat loss.
ML lines in BW, or even a noticeable trend over the 15 generations of selection.

Least squares means for BW of males and females under different environmental temperatures at different ages are in Table 4. At 6 and 9 wk of age, there was an environment $\times$ sex interaction $(P<0.05)$ for BW. The differences in BW between males and females were greater in the $\mathrm{H}$ environment than in the $\mathrm{C}$ environment. At all ages, males were heavier $(P<0.001)$ than females under all environmental temperatures, except in the $\mathrm{C}$ environment at $3 \mathrm{wk}$ of age, where males and females had similar BW. Greater BW in animals of both sexes were recorded in the $\mathrm{N}\left(22^{\circ} \mathrm{C}\right)$ environment, and lower BW in either of the other two environmental temperatures at all ages.

Biggers et al. (1958) observed that the growth of mice in the $\mathrm{C}$ environment $\left(5^{\circ} \mathrm{C}\right)$ was depressed relative to growth in the $\mathrm{H}$ environment and noted nonsignificant differences between mice in the $\mathrm{H}\left(28^{\circ} \mathrm{C}\right)$ and $\mathrm{N}\left(21^{\circ} \mathrm{C}\right)$ environments. Wilson et al. (1972) reported 6-wk BW of $22.70,19.81$, and $21.35 \mathrm{~g}$ in a four-way composite strain of mice in $\mathrm{N}\left(21^{\circ} \mathrm{C}\right), \mathrm{C}\left(12^{\circ} \mathrm{C}\right)$, and $\mathrm{H}\left(30^{\circ} \mathrm{C}\right)$ environments, respectively, also confirming more depressed growth in the $\mathrm{C}$ than in the $\mathrm{H}$ environment. Lopez et al. (1991) reported that exposing finishing swine to cold diurnal temperatures between -5 to $8^{\circ} \mathrm{C}$ resulted in pigs that grew $27.2 \%$ more slowly than their thermoneutral counterparts maintained at $20^{\circ} \mathrm{C}$. Jesse et al. (1991) reported that exposing finishing swine to a $\mathrm{H}$ environment $\left(28.5^{\circ} \mathrm{C}\right)$ resulted in pigs that grew $16.3 \%$ more slowly than their thermoneutral counterparts at $20^{\circ} \mathrm{C}$.

Although the effects of both cold and heat stress in this study varied between the sexes and with age, the findings are fairly consistent with the above studies and demonstrate that both heat and cold stress adversely affect growth in animals. In the $\mathrm{C}$ environment, a higher proportion of the nutrients consumed went toward the maintenance of a constant body temperature, leaving little for production or growth. In the $\mathrm{H}$ environment, the depression of appetite limits the 
Table 4. Least squares means $( \pm S E)$ for body weight $(\mathrm{g})$ by environment-sex classes at different ages of the mice

\begin{tabular}{|c|c|c|c|c|c|c|}
\hline \multirow[b]{2}{*}{ Age, $w^{a}$} & \multicolumn{2}{|c|}{ Cold $\left(\mathrm{C}, 12^{\circ} \mathrm{C}\right)$} & \multicolumn{2}{|c|}{ Normal $\left(\mathrm{N}, 22^{\circ} \mathrm{C}\right)$} & \multicolumn{2}{|c|}{$\operatorname{Hot}\left(\mathrm{H}, 31^{\circ} \mathrm{C}\right)$} \\
\hline & Males & Females & Males & Females & Males & Females \\
\hline $3^{b}$ & $11.73 \pm 0.49$ & $11.39 \pm 0.50$ & $14.54 \pm 0.49$ & $13.69 \pm 0.49$ & $14.15 \pm 0.49$ & $13.46 \pm 0.49$ \\
\hline $6^{\mathrm{c}}$ & $26.89 \pm 0.64$ & $23.84 \pm 0.64$ & $29.45 \pm 0.63$ & $25.03 \pm 0.63$ & $27.64 \pm 0.63$ & $23.10 \pm 0.63$ \\
\hline $9^{d}$ & $32.46 \pm 0.75$ & $27.52 \pm 0.75$ & $33.71 \pm 0.75$ & $27.93 \pm 0.75$ & $31.82 \pm 0.75$ & $25.85 \pm 0.75$ \\
\hline
\end{tabular}

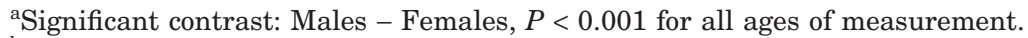

bSignificant contrasts: $(\mathrm{H}+\mathrm{C}) / 2-\mathrm{N}, P<0.02 ; \mathrm{H}-\mathrm{C}, P<0.01$.

'Significant contrasts: $(\mathrm{H}+\mathrm{C}) / 2-\mathrm{N}, P<0.04 ;[\mathrm{H}-\mathrm{C}] \times[$ Males - Females], $P<0.001$.

${ }^{\mathrm{d}}$ Significant contrast: $[\mathrm{H}-\mathrm{C}] \times[$ Males - Females $], P<0.02$.

availability of nutrients for growth and consequently decreases growth and development in mice. The greater BW in males than in females confirm the observation that in most mammalian species, males grow more rapidly than females of similar ages through the effects of different hormone profiles.

Nonsignificant line $\times$ environment interaction for BW is not consistent with the a priori hypothesis, which postulated significant line $\times$ environment interaction for BW. All three lines were thus similarly affected by the three environmental temperatures. Similar BW between the lines at different environmental temperatures suggest that selected lines ( $\mathrm{MH}$ and ML) have the capability to make physiological, morphological, and behavioral adjustments to accommodate differences in heat loss. Live weights are however less informative because there might be some differences between the lines in lean yield and body composition.

\section{Body Dimensions, Organ Weights, and Body Fat}

Least squares means for the relative lengths of the body and tail, percentage of body fat, and body organs as a percentage of BW for the MH, MC, and ML lines are given in Table 5 . There were no differences $(P>$ 0.12 ) in the lengths of the body and tail among the three lines. There were also no differences $(P>0.20)$ in the percentage weights of the tail and the liver among the lines. Similar liver weight percentages among the three lines in the current study contradict the findings of Moody et al. (1997), who obtained significantly greater liver weight percentages in the $\mathrm{MH}$ than in the ML line. Perhaps the sample size was not large enough in the current study to detect the difference between the lines. Percentage of spleen weight did tend to be greater $(P<0.10)$ in the $\mathrm{MH}$ than the ML; this was consistent with Moody et al. (1997) findings.

At $9 \mathrm{wk}$ of age, there was a difference in the percentage of body fat $(P<0.003)$ between the $\mathrm{MH}$ and $\mathrm{ML}$ lines, and there was no indication $(P>0.55)$ of asymmetry of selection response. The ML line had the highest percentage of body fat, and the MH line had the least. The percentage of body fat in the MC line mice was intermediate to those of the two selected lines. Differences in percentage of body fat among lines obtained in this study are larger but consistent with those reported by Nielsen et al. (1997a), who reported 16.0, 16.4 , and $16.9 \%$ body fat in the $\mathrm{MH}, \mathrm{MC}$, and ML lines, respectively, at $12 \mathrm{wk}$ of age using a different method of measurement. Swallow et al. (2001) reported significantly lower percentages of body fat in mice selected for higher activity levels compared with the unselected controls using a hydrogen-isotope dilution method (12 vs. $15 \%$ body fat for males and 11 vs. $15.5 \%$ body fat for females). Mousel et al. (2001) reported that activity levels in the $\mathrm{MH}$ mice were double those in the ML mice, which might explain in part the lower percentage of body fat in the MH vs. the ML line.

The absolute difference in percentage of body fat between the MH and ML lines was 1.87\%. When converted

Table 5. Least squares means $( \pm S E)$ for relative lengths of the body and tail and weights of some body organs and body fat as a percentage of body weight at 9 wk of age by selection line ${ }^{\mathrm{a}}$

\begin{tabular}{lrrr}
\hline \hline Trait $^{\mathrm{b}}$ & \multicolumn{1}{c}{ MH } & \multicolumn{1}{c}{ MC } & \multicolumn{1}{c}{ ML } \\
\hline Body length, mm/g BW & $3.45 \pm 0.08$ & $3.28 \pm 0.08$ & $3.31 \pm 0.08$ \\
Tail length, mm/g BW & $2.93 \pm 0.07$ & $2.84 \pm 0.07$ & $2.82 \pm 0.07$ \\
Tail weight, \% & $2.31 \pm 0.07$ & $2.34 \pm 0.07$ & $2.35 \pm 0.07$ \\
Liver weight, \% $_{\text {Spleen weight, \% }}^{\mathrm{c}}$ & $5.86 \pm 0.19$ & $5.94 \pm 0.19$ & $5.60 \pm 0.19$ \\
Body fatness, \% $^{\mathrm{d}}$ & $0.51 \pm 0.02$ & $0.47 \pm 0.02$ & $0.45 \pm 0.02$ \\
\hline
\end{tabular}

${ }^{\mathrm{a}} \mathrm{MH}=$ selected for high heat loss; $\mathrm{MC}=$ control; $\mathrm{ML}=$ selected for low heat loss.

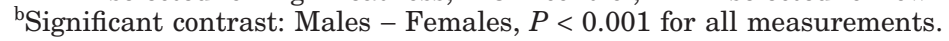

'Significant contrast: $\mathrm{MH}-\mathrm{ML}, P<0.10$.

dignificant contrast: $\mathrm{MH}-\mathrm{ML}, P<0.003$. 
Table 6. Least squares means $( \pm S E)$ for some body organs as a percentage of body weight by environment at $9 \mathrm{wk}$ of age

\begin{tabular}{lccc}
\hline \hline Trait, \% & Cold $\left(\mathrm{C}, 12^{\circ} \mathrm{C}\right)$ & Normal $\left(\mathrm{N}, 22^{\circ} \mathrm{C}\right)$ & Hot $\left(\mathrm{H}, 31^{\circ} \mathrm{C}\right)$ \\
\hline Tail weight $^{\mathrm{a}}$ & $1.85 \pm 0.05$ & $2.37 \pm 0.05$ & $2.78 \pm 0.05$ \\
Liver weight $^{\mathrm{a}}$ & $6.76 \pm 0.18$ & $5.83 \pm 0.18$ & $4.82 \pm 0.18$ \\
Spleen weight $^{\mathrm{b}}$ & $0.52 \pm 0.02$ & $0.48 \pm 0.02$ & $0.43 \pm 0.02$ \\
\hline
\end{tabular}

a Significant contrast: $\mathrm{H}-\mathrm{C}, P<0.001$.

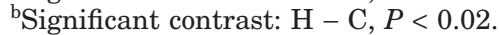

to a relative comparison, ML mice were $13 \%$ fatter than $\mathrm{MH}$ mice. This is much smaller than the difference of $6.77 \%$ (40\% relative difference) reported by Moody et al. (1997) with these same lines using direct chemical analysis to estimate composition at $16 \mathrm{wk}$ of age. The combination of different ages and different assay techniques limits the direct comparison of the two sets of data. Even though the ML mice consume less feed than the MH mice, they are fatter, a reflection of their greatly lower maintenance requirements.

Least squares means for body organ weights as a percentage of BW under different environmental temperatures are provided in Table 6. Mice in the $\mathrm{H}$ environment had the heaviest tails and those in the $\mathrm{C}$ environment had the lightest tails $(P<0.001)$. Tail weights in the $\mathrm{N}$ environment were intermediate to those in the $\mathrm{H}$ and $\mathrm{C}$ environments. At 9 wk of age, mice in the $\mathrm{H}$ environment had tails that were 17 and $50 \%$ heavier than those of their age-matched counterparts in the $\mathrm{N}$ and $\mathrm{C}$ environments, respectively. The tail is the major thermoregulatory organ in mice and therefore becomes longer in $\mathrm{H}$ environmental conditions to aid in the dissipation of heat. In the $\mathrm{C}$ environment, the opposite helps minimize heat loss.

There was a difference in liver weight $(P<0.001)$ between mice in the $\mathrm{C}$ and $\mathrm{H}$ environments, and there was no indication $(P>0.70)$ of asymmetry of extreme temperatures effect on liver weight. Animals in the C environment had the heaviest livers and those in the $\mathrm{H}$ environment had the lightest livers $(P<0.002)$. At 9 wk of age, mice in the $\mathrm{C}$ environment had livers that were $16 \%$ and $40 \%$ heavier than those in the $\mathrm{N}\left(22^{\circ} \mathrm{C}\right)$ and $\mathrm{H}\left(31^{\circ} \mathrm{C}\right)$ environments, respectively. Heroux and
Gridgeman (1958) also reported heavier livers and kidneys in rats reared at $6^{\circ} \mathrm{C}$ for a few weeks. The liver plays a very important role in metabolism, and the increased level of metabolism with greater feed intake in the $\mathrm{C}$ environment is therefore accompanied by a proportionate increase in the size and weight of the liver. In the $\mathrm{H}$ environment, the opposite of what happens in the $\mathrm{C}$ environment normally occurs resulting in smaller and lighter livers. The weight of the liver, therefore, serves as a crude index of metabolic rate. The proportionate increase in liver weight in comparing the $\mathrm{C}$ and $\mathrm{H}$ environments (40\%) is, however, less than the corresponding proportionate increase in feed intake $(90 \%)$.

There was a difference in spleen weight $(P<0.02)$ between the animals in the $\mathrm{C}$ and $\mathrm{H}$ environments, and there was no indication of asymmetry of extreme temperatures effect on spleen weight. Spleen weights tended to follow a similar pattern to that of liver weights. The heaviest spleens were from animals reared in the $\mathrm{C}$ environment and the lightest were from animals reared in the $\mathrm{H}$ environment. The spleen is indirectly involved in the transformation and transportation of nutrients throughout the body and is also involved in the regulation of feed intake and the sense of taste. Large functional spleens are associated with greater appetite and higher feed intake. Larger spleens in the $\mathrm{C}$ environment are therefore a reflection of increased feed intake caused by increased rate of metabolism.

There were also differences in tail weight (2.45 vs. $2.22 \%, P<0.001)$, liver weight $(5.55$ vs. $6.06 \%, P<$ $0.001)$, and spleen weight $(0.51$ vs. $0.45 \%, P<0.002)$ as a proportion of BW between females and males, respectively. At 9 wk of age, females had tails that were $10 \%$ longer and spleens that were $13 \%$ heavier than those of their male counterparts. At 9 wk of age, livers were $9 \%$ heavier in males than in females. Males have larger bodies, consume more feed, and therefore process more nutrients than females. The differences in feed intake per metabolic size (Table 2) between the two sexes therefore explain the observed difference in the size or weight of the liver between males and females. No obvious explanation exists for larger spleens and tails in females than in males.

Table 7. Least squares means ( \pm SE) for body length, tail length, and percentage of body fat by environment-sex classes at 9 wk of age

\begin{tabular}{|c|c|c|c|c|c|c|}
\hline \multirow[b]{2}{*}{ Trait $^{\mathrm{a}}$} & \multicolumn{2}{|c|}{ Cold $\left(\mathrm{C}, 12^{\circ} \mathrm{C}\right)$} & \multicolumn{2}{|c|}{ Normal $\left(\mathrm{N}, 22^{\circ} \mathrm{C}\right)$} & \multicolumn{2}{|c|}{ Hot $\left(\mathrm{H}, 31^{\circ} \mathrm{C}\right)$} \\
\hline & Males & Females & Males & Females & Males & Females \\
\hline $\mathrm{BL}^{\mathrm{b}}$ & $3.06 \pm 0.09$ & $3.46 \pm 0.09$ & $3.06 \pm 0.09$ & $3.57 \pm 0.09$ & $3.15 \pm 0.09$ & $3.78 \pm 0.09$ \\
\hline $\mathrm{TL}^{\mathrm{c}}$ & $2.10 \pm 0.08$ & $2.47 \pm 0.08$ & $2.60 \pm 0.08$ & $3.12 \pm 0.08$ & $3.13 \pm 0.08$ & $3.78 \pm 0.08$ \\
\hline $\mathrm{BF}^{\mathrm{d}}$ & $13.13 \pm 0.91$ & $14.22 \pm 0.91$ & $14.81 \pm 0.91$ & $16.57 \pm 0.91$ & $15.06 \pm 0.91$ & $18.00 \pm 0.91$ \\
\hline
\end{tabular}

${ }^{\mathrm{a} B L}=$ body length $(\mathrm{mm} / \mathrm{g} \mathrm{BW}) ; \mathrm{TL}=$ tail length $(\mathrm{mm} / \mathrm{g} \mathrm{BW}) ; \mathrm{BF}=$ body fatness as a percentage of BW. Significant contrast: Males - Females, $P<0.001$ for all traits.

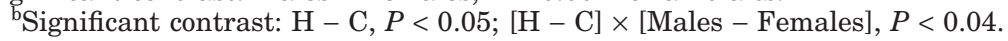

'Significant contrast: $\mathrm{H}-\mathrm{C}, P<0.001 ;[\mathrm{H}-\mathrm{C}] \times[$ Males - Females], $P<0.005$.

dSignificant contrast: $\mathrm{H}-\mathrm{C}, P<0.02 ;[\mathrm{H}-\mathrm{C}] \times[$ Males - Females $], P<0.06$. 
Least squares means for the relative lengths of the body and tail and average percentage of body fat for males and females at different environmental temperatures are in Table 7 . At 9 wk of age, there were environment $\times$ sex interactions for body length, tail length, and percentage of body fat. Differences in body length, tail length, and percentage of body fat between the two sexes were greater in the $\mathrm{H}$ environment than in the $\mathrm{C}$ environment, resulting in significant environment $x$ sex interactions. Females were longer per unit weight than males $(P<0.001)$ in all the environments. Females were 13,16 , and $20 \%$ longer than males in the $\mathrm{C}, \mathrm{N}$, and $\mathrm{H}$ environments, respectively. In both sexes, the differences in body length between mice in the $\mathrm{H}$ and $\mathrm{C}$ environments were also evident $(P<0.05)$. At $9 \mathrm{wk}$ of age, mice in the $\mathrm{H}$ environment were the longest and those in the $\mathrm{C}$ the shortest. The body lengths of mice in the $\mathrm{N}$ environment were intermediate to those in the $\mathrm{H}$ and $\mathrm{C}$ environments.

The finding of longer bodies for mice in the $\mathrm{H}$ environment is consistent with the observation of Dauncey and Ingram (1986) that at 9 wk of age, pigs raised in a $\mathrm{H}$ environment $\left(30^{\circ} \mathrm{C}\right)$ had an elongated appearance with long ears and long snouts. However, Barnett and Scott (1963) and Scholander (1955) reported very small and nonsignificant differences in body dimensions between mice in the $\mathrm{H}$ and $\mathrm{C}$ environmental conditions. The elongated bodies in the $\mathrm{H}$ environment serve to provide a larger surface area for the dissipation of heat. Relatively shorter bodies in the $\mathrm{C}$ environment reduce total surface area to minimize heat loss.

Females had longer tails $(P<0.001)$ than their male counterparts across the different environments at $9 \mathrm{wk}$ of age. There were also differences $(P<0.001)$ in tail lengths between mice raised in the $\mathrm{H}$ and $\mathrm{C}$ environments. Mice in the $\mathrm{H}$ environment had the longest tails, and those in the $\mathrm{C}$ had the shortest tails. Tail lengths in the $\mathrm{N}$ environment were intermediate to tail lengths in the $\mathrm{H}$ and $\mathrm{C}$ environments. Tails of mice in the $\mathrm{H}$ environment were, therefore, not only the heaviest but also the longest, and those in the $\mathrm{C}$ environment the lightest and shortest. Tails of mice in the $\mathrm{N}$ environment were intermediate in both length and weight.

These findings are consistent with those of Dauncey and Ingram (1986), who observed shorter tails in pigs raised in a $\mathrm{C}$ environment and longer tails in their agematched counterparts in a $\mathrm{H}$ environment. Demicka and Caputa (1993) also observed longer tails in 3-moold warm-reared $\left(34\right.$ to $35^{\circ} \mathrm{C}$ ) rats in contrast to the control rats at 20 to $25^{\circ} \mathrm{C}$. Summer (1915) and Emery et al. (1940) reported shorter tails in mice and rats raised in $\mathrm{C}$ environmental conditions, respectively. Wilson et al. (1972) also reported relatively shorter tails in two composite strains of mice as a result of cold exposure $\left(12^{\circ} \mathrm{C}\right)$ and elongation of tails in the same strains in the $\mathrm{H}$ environment $\left(30^{\circ} \mathrm{C}\right)$. At $6 \mathrm{wk}$ of age, tail length in the $\mathrm{C}$ environment was reduced by approximately $29 \%$ and increased by $11 \%$ in the $\mathrm{H}$ environment. Because the tail is the major thermoregulatory organ in mice, it is not surprising to find animals with longer tails in the $\mathrm{H}$ environment and those with shorter tails in the $\mathrm{C}$ environment.

Longer bodies and tails of females in contrast to those of males are consistent with the findings of Demicka and Caputa (1993) who observed that tails of females were relatively longer than those of males. Longer bodies of females observed in this study, however, are in contrast to the proposal of Barnett and Scott (1963) that lighter animals or mice are proportionally shorter (from nose tip to anus) than heavier members (males are heavier than females) of the same strain. No obvious explanation exists for the observed differences in body length and tail length between males and females, but may help explain the superiority of female rodents in withstanding thermal stresses (Zarrow and Denison, 1956; Doi and Kuroshima, 1982).

Females were also fatter $(P<0.001)$ than males across different environmental temperatures. The differences in body fat between females and males at 9 wk of age in the $\mathrm{C}, \mathrm{N}$ and $\mathrm{H}$ environmental conditions were $1.09,1.76$, and $2.94 \%$, respectively. In both sexes, mice had the highest percentage of body fat in the $\mathrm{H}$ environment and the lowest in the $\mathrm{C}$ environment. The percentage of body fat of the animals in the $\mathrm{N}$ environment was intermediate to those in the $\mathrm{C}$ and $\mathrm{H}$ environments. In both sexes, differences in percentage of body fat between animals in the $\mathrm{C}$ and $\mathrm{H}$ environments were detected $(P<0.05)$.

The lowest percentage of body fat recorded in mice from the $\mathrm{C}$ environment is consistent with the findings of Heroux and Gridgeman (1958) and Young and Cook (1951), who reported that unlike in other mammals, exposure of mice and rats to severe cold results in loss of body fat. Barnett and Manly (1956) also reported that exposure of the A2G strain of mice to cold $\left(-3^{\circ} \mathrm{C}\right)$ led to a decrease in body fat of approximately $41 \%$ compared with the controls at $21^{\circ} \mathrm{C}$. The highest percentage of body fat in the $\mathrm{H}$ environment is consistent with the findings of Baker and Cockrem (1970), who reported a significantly higher percentage of body fat in mice in the $\mathrm{H}$ ( 11.3 and $13.45 \%$ body fat for males and females, respectively) than in the $\mathrm{N}$ (8.6 and $9.8 \%$ body fat for males and females, respectively) and $\mathrm{C}$ environments (7.9 and $10.2 \%$ body fat for males and females, respectively). The differences in body fat between the two sexes confirm the generally observed fact that, in mammals of the same contemporary group, females grow fatter than males. The higher percentage of body fat in females contributes to their expected superiority to males in more efficiently resisting cold stress.

Finding the highest percentage of body fat in $\mathrm{H}$ environment animals was not expected but suggests that an important portion of the feed consumed by mice goes toward maintenance of a constant body temperature. In the $\mathrm{H}$ environment, very little energy is goes to maintenance of a constant body temperature, leaving more consumed energy available for possible conversion into body fat. In the $\mathrm{C}$ environment, a large proportion of 
the energy consumed is goes to maintenance of a constant body temperature, leaving very few calories to be converted into body fat, hence the observed differences in body fat between in the $\mathrm{H}$ and $\mathrm{C}$ environment animals. It may be that animals in the $\mathrm{H}$ environment did not reduce their appetite enough and those in the $\mathrm{C}$ environment did not increase their appetite enough to maintain similar body fat levels across environments.

The absence of a significant line $\times$ environment interaction for body length, tail length, spleen weight, and liver weight does not support the $a$ priori hypothesis which postulated a significant line $\times$ environment interaction for the lengths and weights of these organs. This also implies that the growth of these organs was similarly affected by different environmental temperatures in all lines (MH, ML, MC). It also implies that growth patterns of these organs in the selected lines (MH and ML) did not contribute significantly to the adaptation of the $\mathrm{MH}$ line to the $\mathrm{C}$ environment and the $\mathrm{ML}$ line to the $\mathrm{H}$ environment. The MH, ML, and MC lines seem equally suited to handle heat and cold stress.

\section{Implications}

No selection line $\times$ thermal environment interactions were detected for feed intake, body and organ weights, and body fat in these mice. This implies that all lines compared similarly when reared in hot or cold environmental temperatures as when reared in normal temperature for all the above traits, possibly through some physiological, morphological, and behavioral adjustments. Results from this study with mice do not raise concern that selection to reduce maintenance requirements in livestock will produce animals with any greater liability to cope and perform with respect to growth, feed intake, or body composition under an array of environmental temperatures.

\section{Literature Cited}

Baker, R. L., and F. R. M. Cockrem. 1970. Selection for body weight in the mouse at three temperatures and the correlated response in tail length. Genetics 65:505-523.

Barnett, S. A., and B. M. Manly. 1956. Reproduction and growth of mice of three strains after transfer to $-3{ }^{\circ} \mathrm{C}$. J. Exp. Biol. 33:325-329.

Barnett, S. A., and S. G. Scott. 1963. Some effects of cold and of hybridity on the growth of mice. J. Embryol. Exp. Morphol. 11:35-51.

Biggers, J. D., M. R. Ashoub, and A. Mclaren. 1958. The growth and development of mice in three climatic environments. J. Exp. Biol. 35:144-155.

Dauncey, M. J., and D. L. Ingram. 1986. Acclimatization to warm or cold temperatures and the role of feed intake. J. Therm. Biol. 11:89-93.
Demicka, A., and M. Caputa. 1993. Effect of warm rearing on the development of thermolytic effectors in rats. J. Therm. Biol. 18:251-256.

Doi, K., and A. Kuroshima. 1982. Sexual difference in thermoregulatory ability of rats exposed to heat and cold. J. Therm. Biol. 7:99-105.

Emery, F. E., L. M. Emery, and E. L. Schwabe. 1940. The effects of prolonged exposure to low temperature on body growth and on weights of organs in albino rats. Growth 4:17-32.

Heroux, O., and N. T. Gridgeman. 1958. The effect of cold acclimation on the size of organs and tissues of the rat. Can. J. Biochem. Physiol. 36:209-216.

Jesse, G. W., J. Lopez, B. A. Becker, and M. R. Ellersieck. 1991. Effects of temperature on the performance of finishing swine: Effects of a cold diurnal temperature on average daily gain, feed intake and feed efficiency. J. Anim. Sci. 69:1850-1855.

Kgwatalala, P. M., J. L. De Roin, and M. K. Nielsen. 2004. Performance of mice lines divergently selected for heat loss when exposed to different environmental temperatures. I. Reproductive performance, pup survival and metabolic hormones. J. Anim. Sci. 82:2876-2883.

Littell, R. C., G. A. Milliken, W. W. Stroup, and R. A. Wolfinger. 1996. SAS. System for Mixed Models. SAS Inst., Inc., Cary, NC.

Lopez, J., G. W. Jesse, B. A. Becker, and M. R. Ellersieck. 1991. Effects of temperature on the performance of finishing swine: Effects of a hot diurnal temperature on average daily gain, feed intake and feed efficiency. J. Anim. Sci. 69:1843-1849.

Moody, D. E., D. Pomp, and M. K. Nielsen. 1997. Variability in metabolic rate, feed intake and fatness among selection and inbred lines of mice. Genet. Res. 70:225-235.

Mousel, M. R., W. W. Stroup, and M. K. Nielsen. 2001. Locomotor activity, core body temperature and circadian rhythms in mice selected for high or low heat loss. J. Anim. Sci. 79:861-868.

Nielsen, M. K., B. A. Freking, L. D. Jones, S. M. Nelson, T. L. Vordenstrass, and B. A. Hussey. 1997a. Divergent Selection for Heat Loss in Mice: II. Correlated responses in feed intake, body mass, body composition and number born through fifteen generations. J. Anim. Sci. 75:1469-1476.

Nielsen, M. K., L. D. Jones, B. A. Freking, and J. A. DeShazer. 1997b. Divergent selection for heat loss in mice: I. Selection applied and direct response through fifteen generations. J. Anim. Sci. 75:1461-1468.

Scholander, P. F. 1955. Evolution of climatic adaptation in homeotherms. Evolution 9:15-26.

Selman, C., T. K. Korhonen, L. Bunger, W. G. Hill, and J. R. Speakman. 2001. Thermoregulatory response of two mouse Mus musculus strains selectively bred for high and low feed intake. J. Comp. Physiol. 8:661-668.

Summer, F. B. 1915. Some studies of environmental influence, heredity, correlation and growth in the white mouse. J. Exp. Zool. 18:325-332.

Swallow, J. G., P. Koteja, P. A. Carter, and T. Garland, Jr. 2001. Food consumption and body composition in mice selected for high wheel-running activity. J. Comp. Physiol. 171:651-659.

Wilson, S. P., D. P. Doolittle, T. G. Dunn, and P. V. Malven. 1972. Effect of temperature stress on growth, reproduction, and adrenocortical function of mice. J. Hered. 63:324-330.

Young, O. P. 1994. Thermoregulatory behavior of outdoor and commensal populations of mice. J. Therm. Biol. 19:213-217.

Young, D. R., and S. F. Cook. 1951. Body lipids in small mammals following prolonged exposures to high and low temperatures. Am. J. Physiol. 181:72-74.

Zarrow, M. X., and M. E. Denison. 1956. Sexual difference in the survival time of rats exposed to low ambient temperature. Am. J. Physiol. 186:216-218. 